Research Article, Issue 3
Analytical Methods in Environmental Chemistry Journal
AMECJ

\title{
A novel sorbent based on metal-organic framework for mercury separation from human serum samples by ultrasound assisted- ionic liquid-solid phase microextraction
}

\author{
Negar Motakef-Kazemi ${ }^{\mathrm{a}, *}$ \\ a, ${ }^{*}$ Department of Medical Nanotechnology, Faculty of Advanced Sciences and Technology, Tehran Medical Sciences, Islamic Azad University, \\ Tehran, Iran.
}

A R T I C L E I N F O:

Received 14 Jul 2019

Revised form 19 Aug 2019

Accepted 30 Aug 2019

Available online 30 Sep 2019

Keywords:

Metal-organic framework;

Ultrasound assisted -micro-solid phase extraction;

Mercury;

Serum samples;

Cold vapor atomic absorption spectrometry

\begin{abstract}
A B S T R A C T
In this research, the metal-organic framework (MOF) as a solid phase was used for separation mercury [Hg (II)] inhuman serum sample by ultrasound assisted- Ionic Liquid-solid phase microextraction procedure (USA- IL- $\mu$-SPE). Mercury extracted from serum sample by $\left[\mathrm{Zn}_{2}(\mathrm{BDC})_{2}(\mathrm{DABCO})\right]_{\mathrm{n}}$ as $\mathrm{MOF}$ at $\mathrm{pH}=8$. Hydrophobic ionic liquid ([BMIM] [PF6]) was used as solvent trap for $\mathrm{Hg}-\mathrm{MOF}-\mathrm{NC}$ from the sample solution. The phase of $\mathrm{Hg}-$ MOF-NC was back extracted by $0.5 \mathrm{~mL}$ of $\mathrm{HNO}_{3}(0.2 \mathrm{~mol} \mathrm{~L}-1)$ and finally mercury concentration determined with cold vaporatomic absorption spectrometry (CV-AAS) after dilution with 0.5 $\mathrm{mL}$ of DW. Under the optimal conditions, the linear range, limit of detection and preconcentration factor were obtained 0.02$5.5 \mu \mathrm{g} \mathrm{L}^{-1}, 6.5 \mathrm{ng} \mathrm{L}^{-1}$ and 9.8 for serum samples, respectively $(\% \mathrm{RSD}<5 \%)$. The validation of methodology was confirmed by standard reference materials (SRM).
\end{abstract}

\section{Introduction}

Today, metal-organic frameworks have received considerable attention as porous coordination polymers (PCPs) and porous hybrid organicinorganic materials because of their unique properties [1-2]. MOFs can be synthesized via selfassembly of metal ions (or metal clusters) as metal centers, and bridging ligands as linkers [3-4]. In recent years, MOFs wildly have been studied for their potential applications in many areas such as gas storage [5], separation [6], catalysis [7], optics

\footnotetext{
* Corresponding author: Negar Motakef-Kazemi

Email: motakef@iaups.ac.ir

https://doi.org/10.24200/amecj.v2.i03.68
}

[8], photonic [9], ion exchange [10], molecular array [11], biomedicine [12], sensing [13], drug delivery [14], luminescent [13, 15], magnetic [16], and semiconductors [17]. Several methods have been proposed to remove hazardous materials from water such as electrochemical [18], chemical coagulation [19], reverse osmosis membrane [20], and adsorbent [21-23]. The absorbent materials have been studied for different species such as nitrobenzene [24-26], phenol [27], p-xylene hydrocarbon [28], dye [2932], heavy metal [33-34], humic acid [35], and nitrate [36-37] from the waste water. Mercury is a chemical element and heavy metal with very toxic effect. This non-essential metal can be distributed 
in the environment, natural products, and human body [38-39]. The exposure to high mercury can be resulted to the changes in the central nervous system, irritability, fatigue, behavioral changes, tremors, headaches, hearing and cognitive loss, dysarthria, incoordination, and hallucinations [40]. Mercury compounds can be harmed the liver and kidneys, resulting some disorder in enzyme activity, illness, and death [41-42]. Recently, the applications of mercury adsorbents are expanded due to increased level and toxic effect [43-44]. In present study, $\mathrm{Zn}_{2}(\mathrm{BDC})_{2}(\mathrm{DABCO}) \mathrm{MOF}$ was synthesized by solvothermal method for mercury absorption from serum and standard solution with CV-AAS by USA- IL- $\mu$-SPE procedure. The 1-octyl-3-methylimidazolium hexafluorophosphate ([OMIM] $\left[\mathrm{PF}_{6}\right]$ ) as a hydrophobic ionic liquid was used for separating of $\mathrm{Hg}$-MOFfrom liquid phase. The proposed method was validated by spike of real samples and CRM (NIST).

\section{Experimental}

\subsection{Reagents and Materials}

All reagents with high purity and analytical grade were purchased from Merck (Darmstadt, Germany), unless otherwise stated. Materials including zinc acetate ehydrate $\left(\mathrm{Zn}(\mathrm{Oac})_{2} \cdot 2 \mathrm{H}_{2} \mathrm{O}\right), 1,4$ benzenedicarboxylic acid (BDC), 1,4-diazabicyclo [2.2.2] octane (DABCO), dimethylformamide (DMF) were used for synthesis of $\mathrm{Zn}_{2}(\mathrm{BDC})_{2}(\mathrm{DABCO})$ MOF. All aqueous solutions were prepared in ultra-pure deionized water $\left(\mathrm{R} \geq 18 \mathrm{M} \Omega \mathrm{cm}^{-1}\right)$ from Milli-Q plus water purification system (Millipore, Bedford, MA, USA). An Hg (II) standard stock solution (1000 $\mathrm{mg} \mathrm{L}^{-1}$ in $1 \%$ nitric acid, $250 \mathrm{~mL}$ ) was purchased from Fluka, Buchs, Switzerland. The experimental and working standard solutions were prepared daily by diluting the stock solutions with deionized water. The solutions were freshly prepared and stored just in a fridge $\left(4{ }^{\circ} \mathrm{C}\right)$ to prevent decomposition. A $0.6 \%(\mathrm{w} / \mathrm{v})$ sodium borohydride reagent solution was prepared daily by dissolving an appropriate amount of $\mathrm{NaBH}_{4}$ in $0.5 \%(\mathrm{w} / \mathrm{v})$ sodium hydroxide and used as a reducing agent. 1-butyl-3-methylimidazolium hexafluorophosphate
[HMIM][PF6] was obtained from Sigma-Aldrich (M) Sdn. Bhd., Malaysia. The $\mathrm{pH}$ adjustments of samples were made using nitric acid $\left(0.1 \mathrm{~mol} \mathrm{~L}^{-1}\right)$ for $\mathrm{pH} \mathrm{1-2,} \mathrm{and} \mathrm{appropriate} \mathrm{buffer} \mathrm{solutions} \mathrm{in-}$ cluding sodium acetate $\left(\mathrm{CH}_{3} \mathrm{COONa} / \mathrm{CH}_{3} \mathrm{COOH}\right.$, 1-2 $\mathrm{mol} \mathrm{L}^{-1}$ ) for $\mathrm{pH} 3.75-5.75$, sodium phosphate $\left(\mathrm{Na}_{2} \mathrm{HPO}_{4} / \mathrm{NaH}_{2} \mathrm{PO}_{4}, 0.2 \mathrm{~mol} \mathrm{~L}^{-1}\right)$ for $\mathrm{pH}$ of 5.8-8.0, and ammonium chloride $\left(\mathrm{NH}_{3} / \mathrm{NH}_{4} \mathrm{Cl}, 0.2 \mathrm{~mol} \mathrm{~L}^{-1}\right)$ for $\mathrm{pH} 8-10$. All the laboratory glassware and plastics were cleaned by soaking in nitric acid $(10 \%$, $\mathrm{v} / \mathrm{v}$ ) for at least $24 \mathrm{~h}$ and then rinsed with deionized water before use. Due to hazardous effects of $\mathrm{Hg}$ solutions, gloves, safety mask, and laboratory hood should be used when mercury standard solutions are prepared.

\subsection{Characterization}

The MOF was characterized by Fourier transform infrared spectroscopy (FTIR), powder X-ray diffraction (XRD), and scanning electron microscope (SEM). FTIR spectra were recorded on a Shimadzuir 460 spectrometer in a $\mathrm{KBr}$ matrix in the range of $400-4000 \mathrm{~cm}^{-1}$. Powder X-ray diffraction pattern was performed for evaluation of crystalline structure of bismuth oxide NP using a Philips Company X'pert diffractometer utilizing $\mathrm{Cu}-\mathrm{Ka}$ radiation (ASENWARE, AW-XBN300, China). Scanning electron microscope was investigated the morphology and MOF (KYKY, EM3200, China). Determination of mercury was performed with an atomic absorption spectrometer (GBC 932- HG3000-AUS, Australia) equipped with a flow injection cold vapor module (FI-CVAAS), deuterium-lamp background corrector, $\mathrm{Hg}$ hollow-cathode lamp, and a circulating reaction loop. The working conditions of FI-CV-AAS were given in Table 1. The $\mathrm{pH}$ values of the solutions were measured by a digital $\mathrm{pH}$ meter (Metrohm, model 744, Herisau, Switzerland). A Hettich centrifuge (model EBA 20, Germany) and an ultrasonic bath with heating system (Tecno-GAZ SPA, Italy) were used throughout this study.

\subsection{Synthesis of MOF}

The $\mathrm{Zn}_{2}(\mathrm{BDC})_{2}(\mathrm{DABCO}) \mathrm{MOF}$ was prepared via 
Table 1. The FI-CV-AAS conditions for determination of mercury in standard samples.

\begin{tabular}{|c|c|}
\hline Features & Value \\
\hline Linear range, $\mu \mathrm{g} \mathrm{L}^{-1}$ & $0.2-55$ \\
\hline Wavelength, nm & 253.7 \\
\hline Lamp current, $\mathrm{mA}$ & 3.0 \\
\hline Slit, nm & 0.5 \\
\hline Mode & Peak area \\
\hline $\mathrm{HCl}$ carrier solution $37 \%$, mol L-1 & 3.0 \\
\hline $\mathrm{NaBH}_{4}$ reducing agent, $\%(\mathrm{~m} / \mathrm{v})$ & $0.6($ in $0.5 \% \mathrm{w} / \mathrm{v} \mathrm{NaOH})$ \\
\hline Argon flow rate, $\mathrm{mL} \mathrm{min}{ }^{-1}$ & 10.0 \\
\hline Sample flow rate, $\mathrm{mL} \min ^{-1}$ & 3.0 \\
\hline Reagent flow rate, $\mathrm{mL} \mathrm{min}^{-1}$ & 5.0 \\
\hline
\end{tabular}

the self-assembly of primary building blocks. In a typical reaction, $\mathrm{Zn}(\mathrm{OAc})_{2} \cdot 2 \mathrm{H}_{2} \mathrm{O}(0.132 \mathrm{~g}, 2$ $\mathrm{mmol})$, BDC (0.1 g, $2 \mathrm{mmol})$, and DABCO (0.035 g, $1 \mathrm{mmol}$ ) were added to $25 \mathrm{ml} \mathrm{DMF}$ [3]. The reactants were sealed under reflux and stirred at 90 ${ }^{\circ} \mathrm{C}$ for $3 \mathrm{~h}$. Then, the reaction mixture was cooled to room temperature, and filtered. The white crystals were washed with DMF to remove any metal and ligand remained, and dried in a vacuum. DMF was removed from white crystals with a vacuum furnace at $150^{\circ} \mathrm{C}$ for $5 \mathrm{~h}$.

\subsection{General procedure of mercury adsorption}

By USA-IL- $\mu$-SPE procedure, $10 \mathrm{~mL}$ polytetrafluoroethylene (PTFE) centrifuge tube was used for this study. First, $10 \mathrm{~mL}$ of serum sample or standard aqueous solution containing $\mathrm{Hg}$ (II) with concentration in the range of 0.1 $5.5 \mu \mathrm{g} \mathrm{\textrm {L } ^ { - 1 }}$ was adjusted to optimum $\mathrm{pH}$ of 8 with sodium phosphate buffer solution $\left(\mathrm{Na}_{2} \mathrm{HPO}_{4} /\right.$ $\mathrm{NaH}_{2} \mathrm{PO}_{4}, 0.2 \mathrm{~mol} \mathrm{~L}^{-1}$ ) and transferred into the $10 \mathrm{~mL}$ PTFE centrifuge tube. Then $50 \mathrm{mg}$ of [OMIM][PF6] dispersed in $100 \mu \mathrm{L}$ acetone was mixed with $20 \mathrm{mg} \mathrm{Zn}_{2}(\mathrm{BDC})_{2}(\mathrm{DABCO})$ as $\mathrm{MOF}$ sorbent and rapidly injected by a syringe into the serum/ standard solution. The resulting mixture was shaken in ultrasonic bath for $5 \mathrm{~min}$ at $25^{\circ} \mathrm{C}$. $\mathrm{Hg}$ (II) was extracted and separation by MOF. The $\left[\mathrm{Zn}_{2}(\mathrm{BDC})_{2}(\mathrm{DABCO})\right]_{\mathrm{n}}-\mathrm{Hg}$ was trapped with IL and centrifuged at $4000 \times \mathrm{g}$ for $3 \mathrm{~min}$. The $\mathrm{Hg}$ $\mathrm{MOF} / \mathrm{IL}$ was settled down in bottom of the conical centrifuge tube and the aqueous phase was removed with a transfer pipette. Finally, mercury species retained on the sorbent were eluted by adding 0.5 $\mathrm{mL}$ of 0.3 molar $\mathrm{HNO}_{3}$ and vigorously shaking the tube for $1 \mathrm{~min}$. The eluent phase was separated by centrifuging of the remaining mixture and $\mathrm{Hg}$ (II) ions were analyzed by CV-AAS after dilution with deionized water up to $1 \mathrm{ml}$. Figure 1 was shown general procedure of mercury adsorption.

\section{Results and Discussion}

\subsection{Fourier transforms infrared spectroscopy for MOF}

The FTIR spectra of MOF were recorded in the range of $400-4000 \mathrm{~cm}^{-1}$ with $\mathrm{KBr}$ pellets by fourier transforms infrared spectroscopy (Fig. 2). The $\mathrm{C}-\mathrm{H}$ aromatic band is shown at $3424 \mathrm{~cm}^{-1}$. The aliphatic $\mathrm{C}-\mathrm{H}$ asymmetric stretching is assigned at $2960 \mathrm{~cm}^{-1}$. The peak at $2357 \mathrm{~cm}^{-1}$ is related to $\mathrm{CO}_{2}$ which exist in environment. The $\mathrm{C}=\mathrm{O}$ stretching and carboxylic group are assigned at $1587 \mathrm{~cm}^{-1}$ and $1387 \mathrm{~cm}^{-1}$ respectively. FTIR spectra corresponded to the reported results [1].

\subsection{X-ray diffraction of MOF}

The XRD measurement was used to determine the crystalline structure of MOF in $2 \theta$ range $\Delta^{\circ}$ to $r . \circ$ (Fig. 3). The position and diffraction properties of the peaks are similar to the pattern of previously reported result [1].

\subsection{Scanning electron microscopy for MOF}

The size and morphology structures of samples 


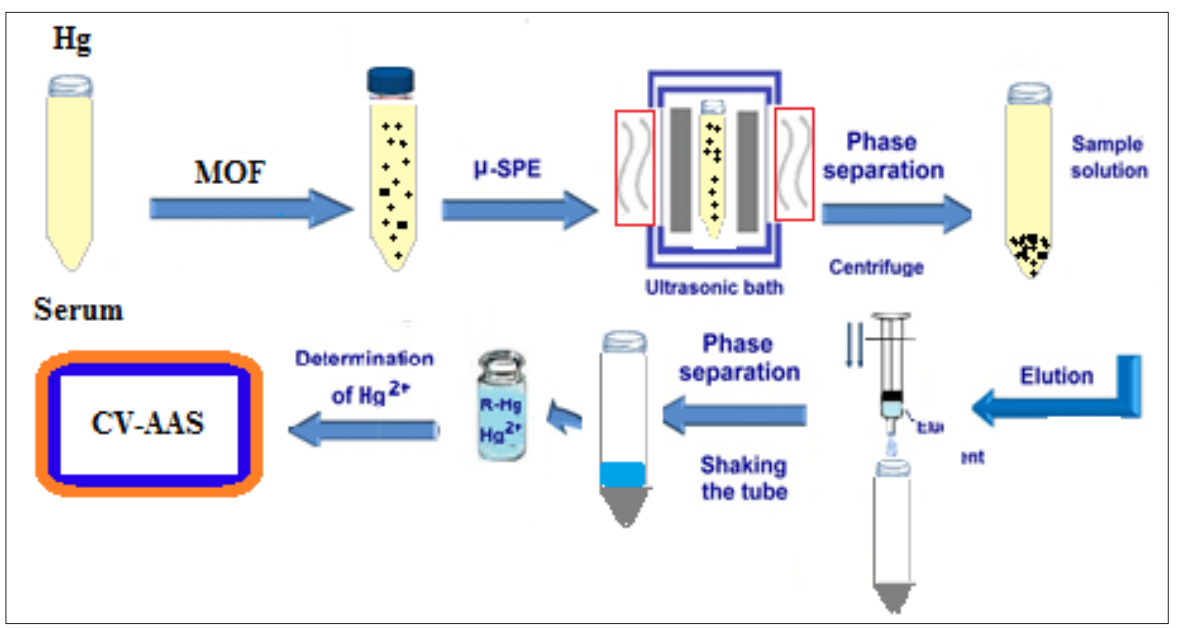

Fig. 1. General procedure of mercury adsorption based on MOF by USA-IL- $\mu-S P E$

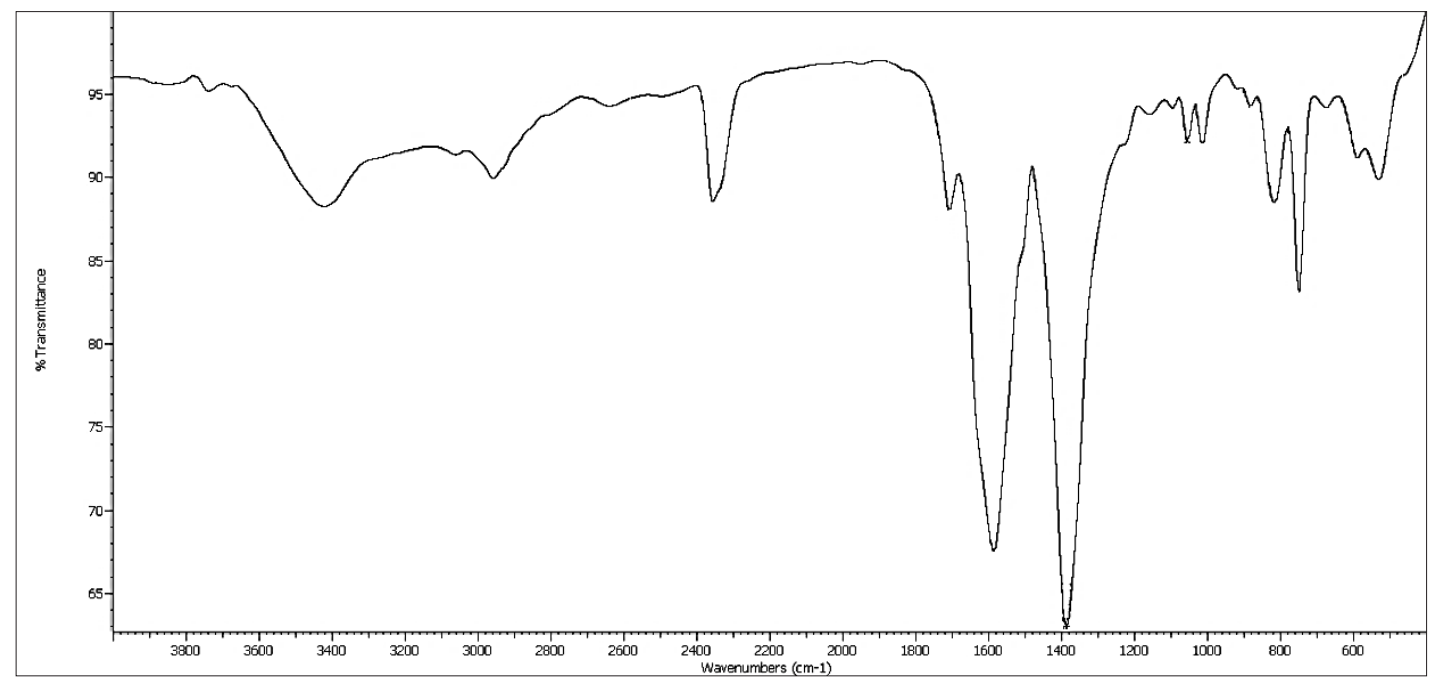

Fig. 2. FTIR spectra of $\mathrm{Zn}_{2}(\mathrm{bdc})_{2}$ (dabco) MOF

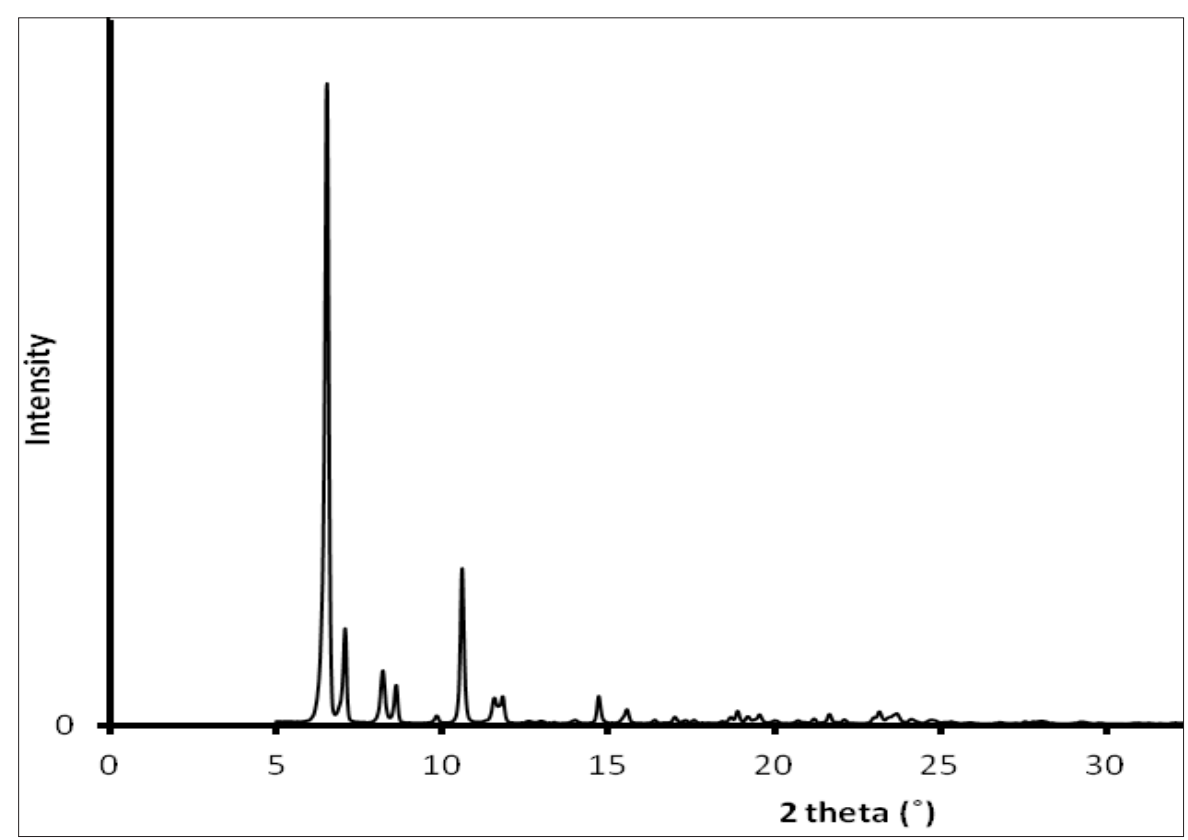

Fig. 3. XRD pattern of $\mathrm{Zn}_{2}(\mathrm{bdc})_{2}(\mathrm{dabco}) \mathrm{MOF}$ 
were studied using SEM that shown rod-shaped with an average diameter of $70 \mathrm{~nm}$, and the length of $350 \mathrm{~nm}$ (Fig. 4).

\subsection{Adsorption mechanism}

The compounds of MOF $\left[\mathrm{Zn}_{2}(\mathrm{bdc})_{2}(\mathrm{dabco})\right]_{\mathrm{n}}$ such as, bdc (COO-) and dabco( N:) was used for chemical extraction of mercury from serum and standard solution samples at optimized $\mathrm{pH}$. These ligands as a suitable material can be extracted the mercury ions in human biological sample at $\mathrm{pH}=8$. The $\mathrm{MOF}$ are coordinating with the cations of $\mathrm{Hg}$ via nitrogen and carbocyclic bond which was deprotonated at basic $\mathrm{pH}$. The mechanism of chemical and physical adsorption carried out by MOF at $\mathrm{pH}$ 7.5-8.5 for mercury in serum samples. The results showed us the recovery of physical adsorption in low $\mathrm{pH}$ without nitrogen covalence bonding $(\mathrm{pH}=3-6)$ was achieved $43.8 \%$ and increased more than $95 \%$ by chemical bonding of MOF with $\mathrm{Hg}(\mathrm{MOF}-\mathrm{N}: \rightarrow \mathrm{Hg})$ at $\mathrm{pH}=7.5-8.5$ (Fig. 5)

\subsection{The optimization}

The optimization was investigated for the ultrasound-assisted ionic liquid-micro solid phase extraction conditions. The USA-IL- $\mu$ SPE procedure provides novel and interesting approach using the MOF sorbent for extraction of mercury from water and serum samples. In order to obtain optimum speciation conditions and quantitative recoveries of inorganic and organic mercury species with good sensitivity and precision, the presented USA- IL$\mu$ SPE method was optimized for various analytical parameters. Moreover, in order to optimization of effecting parameters, standard solutions containing different concentrations of $\mathrm{Hg}$ (II) in the range of 0.1-5.5 $\mu \mathrm{g} \mathrm{L}^{-1}$ were examined.

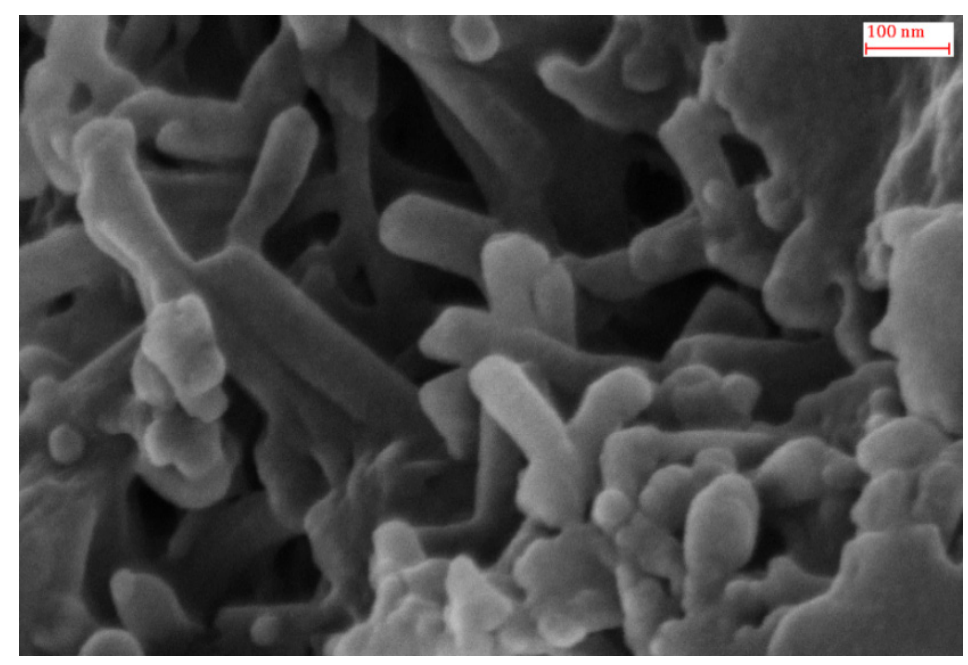

Fig. 4. SEM of $\mathrm{Zn}_{2}(\mathrm{bdc})_{2}($ dabco $) \mathrm{MOF}$

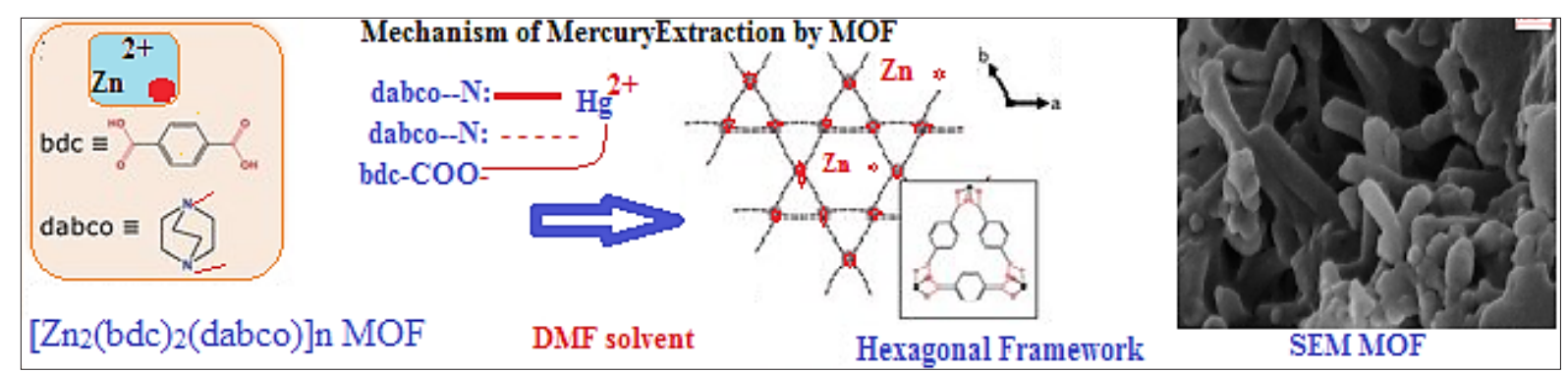

Fig. 5. The mechanism of mercury absorption by MOF 


\subsubsection{Back extraction of mercury from MOF}

The recovery percentage was investigated for mercury absorption by MOF in presence of different acids such as $\mathrm{HNO}_{3}, \mathrm{HCl}, \mathrm{H}_{2} \mathrm{SO}_{4}$, and $\mathrm{CH}_{3} \mathrm{COOH}$ (Fig. 6), and selected 0.3 molar $\mathrm{HNO}_{3}$ as optimum.

\subsubsection{The pH effect of MOF}

The $\mathrm{pH}$ of the sample is an important role to high recovery and extraction of $\mathrm{Hg}$ in human serum matrixes. The effect of serum $\mathrm{pH}$ on the extraction of $\mathrm{Hg}(\mathrm{II})$ based on MOF has studied from $\mathrm{pH}$ of 2 to 11 , containing $0.1-5.5 \mu \mathrm{g} \mathrm{L}{ }^{-1}$ of standard $\mathrm{Hg}(\mathrm{II})$ by USA- IL- $\mu$-SPE method. Based on Figure 7, the extraction of $\mathrm{Hg}$ ions in serum and standard solution samples were increased between $\mathrm{pH}$ from 7.5 to 8.5. The recovery of mercury extraction were achieved more than $95 \%$ in $\mathrm{pH}=8$ and decreased at $\mathrm{pH}$ more than 8.5 and less than 7.5. Consequently, the $\mathrm{pH}$ of 8 was used in further study for $\mathrm{Hg}$ extraction from serum and standard solution samples. In addition, the extra extraction of mercury was achieved by increasing MOF mass but, some of essential metals $(\mathrm{Cu}, \mathrm{Zn}, \mathrm{Ca}, \mathrm{Mn}, \mathrm{Mg}$,) may be removed from

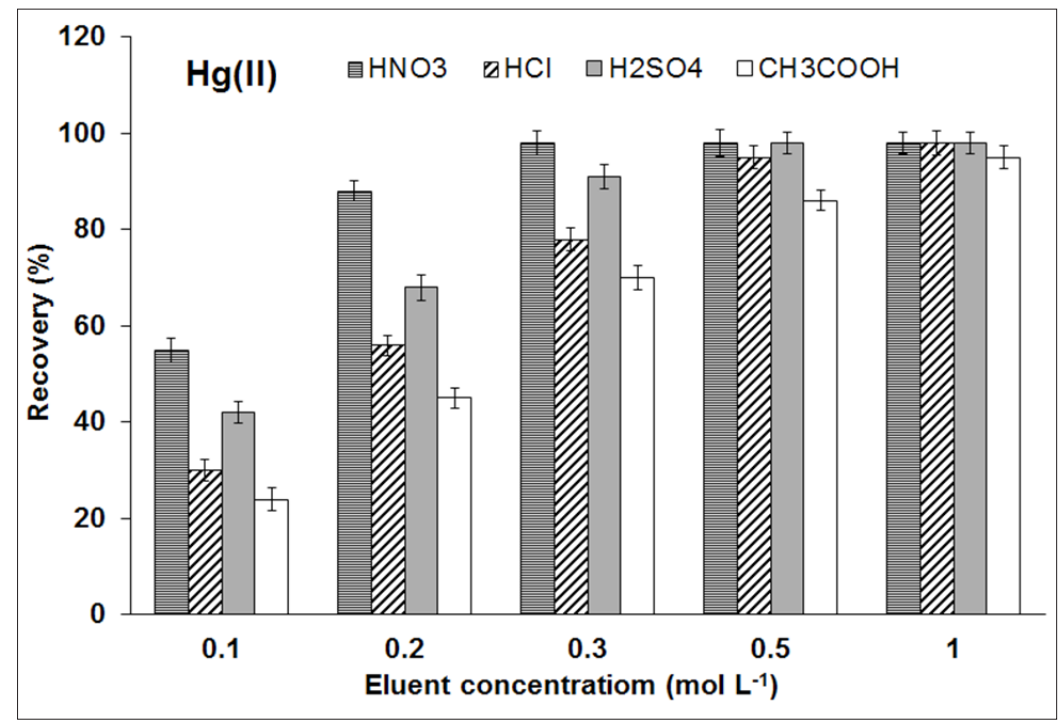

Fig. 6. Recovery percentage in presence of different acids

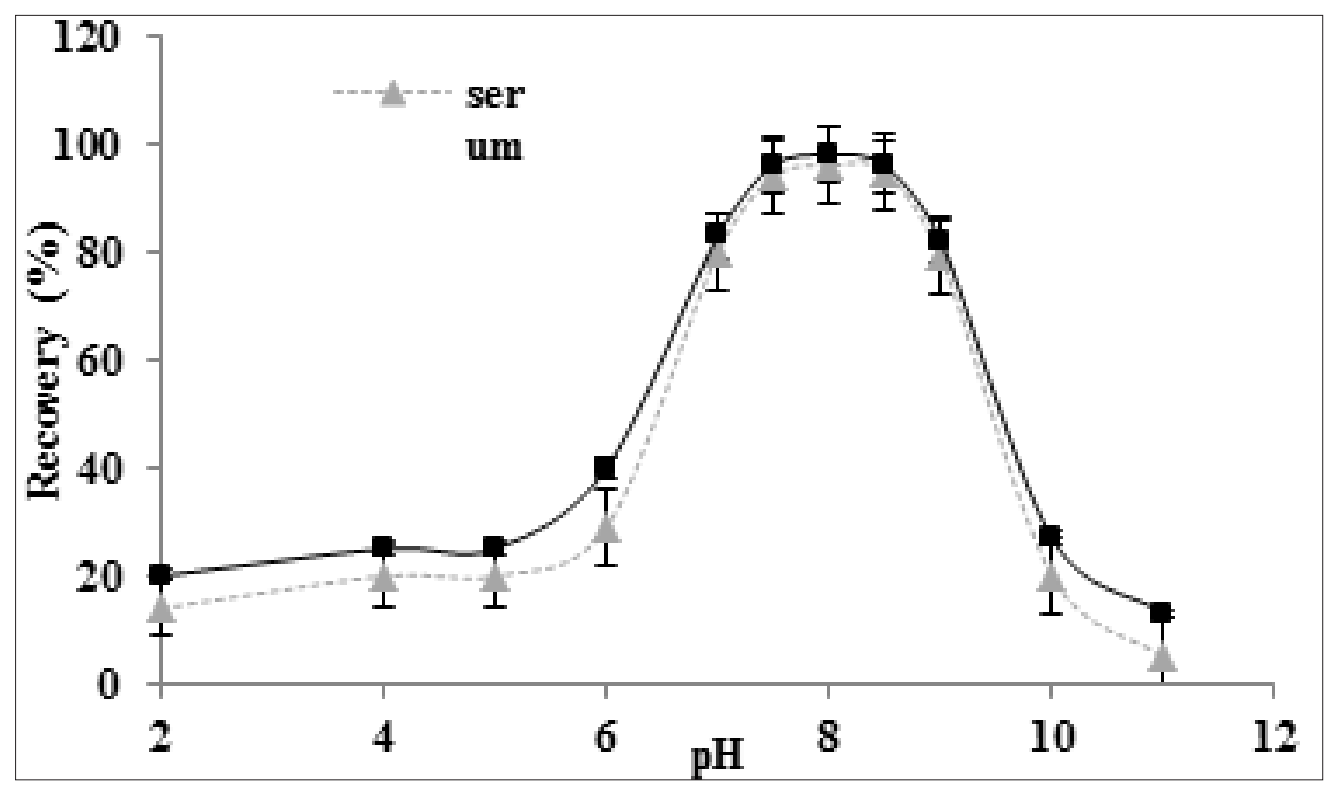

Fig.7. The effect of $\mathrm{pH}$ on mercury extraction by $\mathrm{MOF}$ 
human body and caused different acute disease. In proposed conditions, the recovery of $\mathrm{Hg}$ extraction was obtained $25 \%$ and $97.6 \%$ by IL and MOF/IL, respectively at $\mathrm{pH}=8$. The mechanism of mercury extraction of $\mathrm{MOF} / \mathrm{IL}$ was mainly obtained by the electrostatic attractions of deprotonated nitrogen and carbocyclic groups $(\mathrm{N}, \mathrm{COO})$ with the positively charged mercury ions at $\mathrm{pH}=8$. At acidic $\mathrm{pH}$, the surface of MOF, especially charge of groups have positive $(+)$ and similar to $\mathrm{Hg}^{2+}$, so, the recovery of extraction mercury was decreased. However, in optimized $\mathrm{pH}$, the MOF sorbent had negative charge and electrostatic attraction caused to extract mercury. At high $\mathrm{pH}$ more than 8.5 , the recovery efficiencies were decreased due to the formation of hydroxyl complexes of mercury $[\mathrm{Hg}$ $(\mathrm{OH}) 2]$. Therefore, $\mathrm{Ph}=8$ selected as optimized $\mathrm{pH}$ by USA- IL- $\mu$-SPE procedure.

\subsubsection{Effect of MOF Mass}

The mass of MOF was evaluated as effective parameter for mercury absorption among 1-40 mg. Based on mass results, the optimal value was mass $20 \mathrm{mg}$ for mercury absorption by the MOF. For optimization of proposed method, the amounts of $\left[\mathrm{Zn}_{2}(\mathrm{bdc})_{2}(\mathrm{dabco})\right]_{\mathrm{n}}$ in the range of 1 to $40 \mathrm{mg}$ were studied for mercury extraction in serum and standard samples. The results showed us, less than $18 \mathrm{mg}$ of MOF caused to decrease the extraction efficiency of mercury. So, $20 \mathrm{mg}$ of $\left[\mathrm{Zn}_{2}(\mathrm{bdc})_{2}(\mathrm{dabco})\right]_{\mathrm{n}}$ was used by USA- IL- $\mu$-SPE procedure (Fig. 8).

\subsubsection{Effect of volume of serum}

The optimized sample volume on the recovery of $\mathrm{Hg}$ (II) ions based on USA- IL- $\mu$-SPE procedure were examined from $1 \mathrm{~mL}$ to $25 \mathrm{~mL}$ of standard and serum samples. The volume of serum was investigated as effective parameter for mercury absorption. Based on the results, the optimal value was obtained less than $18 \mathrm{ml}$ for water sample by the MOF. By results, the quantitative recovery was achieved $(<95 \%)$ for $15 \mathrm{~mL}$ and $12 \mathrm{~mL}$ of standard solution and serum, respectively with concentration of $0.1-5.5 \mu \mathrm{g} \mathrm{L}^{-1}$ of mercury (CV-AAS). The recovery was decreased more than $12 \mathrm{~mL}$ and 15 $\mathrm{mL}$ for volume of serum and standard samples by proposed method. So, $10 \mathrm{~mL}$ of volume sample was used by USA- IL- $\mu$-SPE method at $\mathrm{pH}=8$ (Fig. 9).

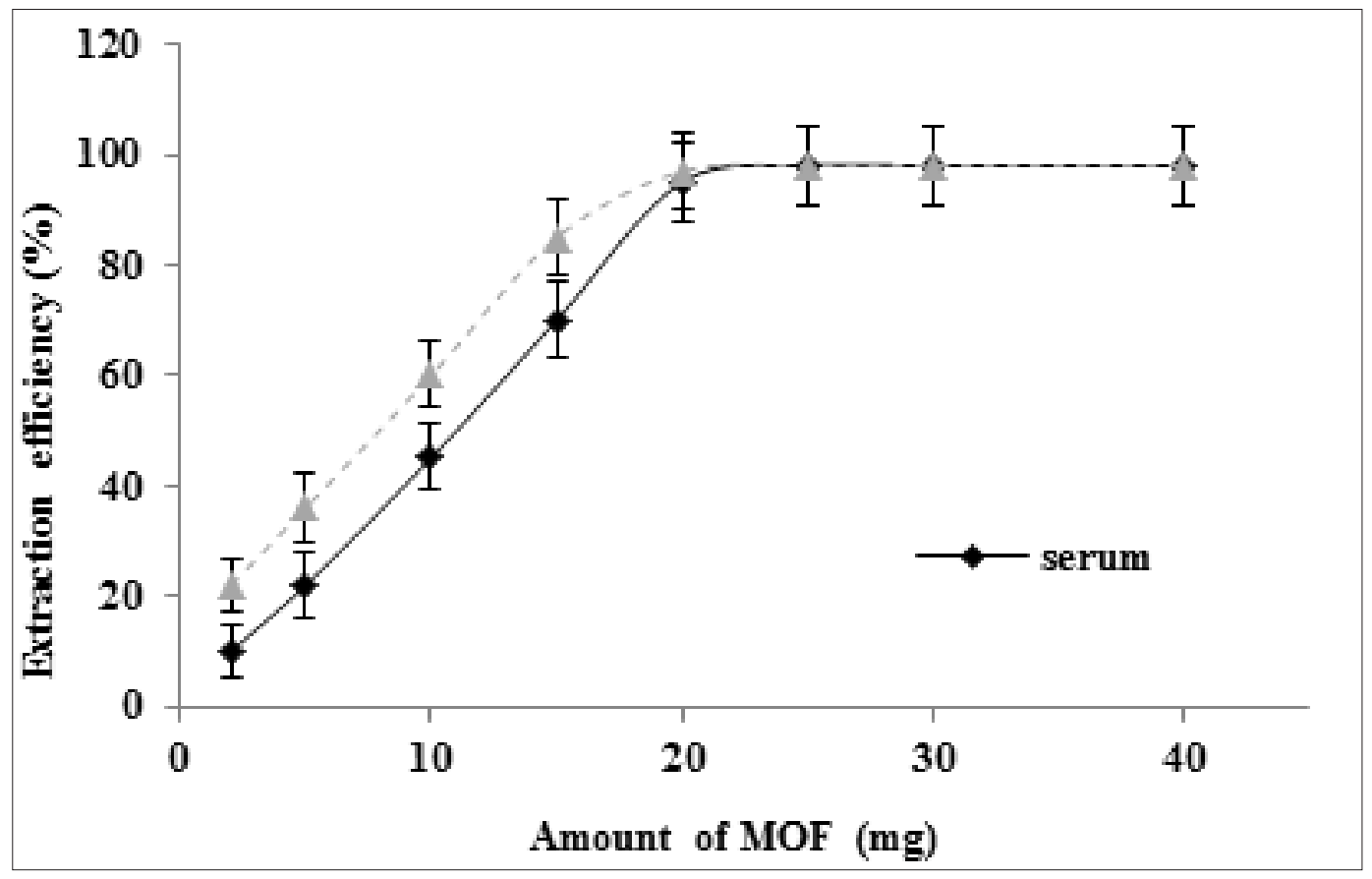

Fig. 8. The effect of MOF mass on mercury extraction 


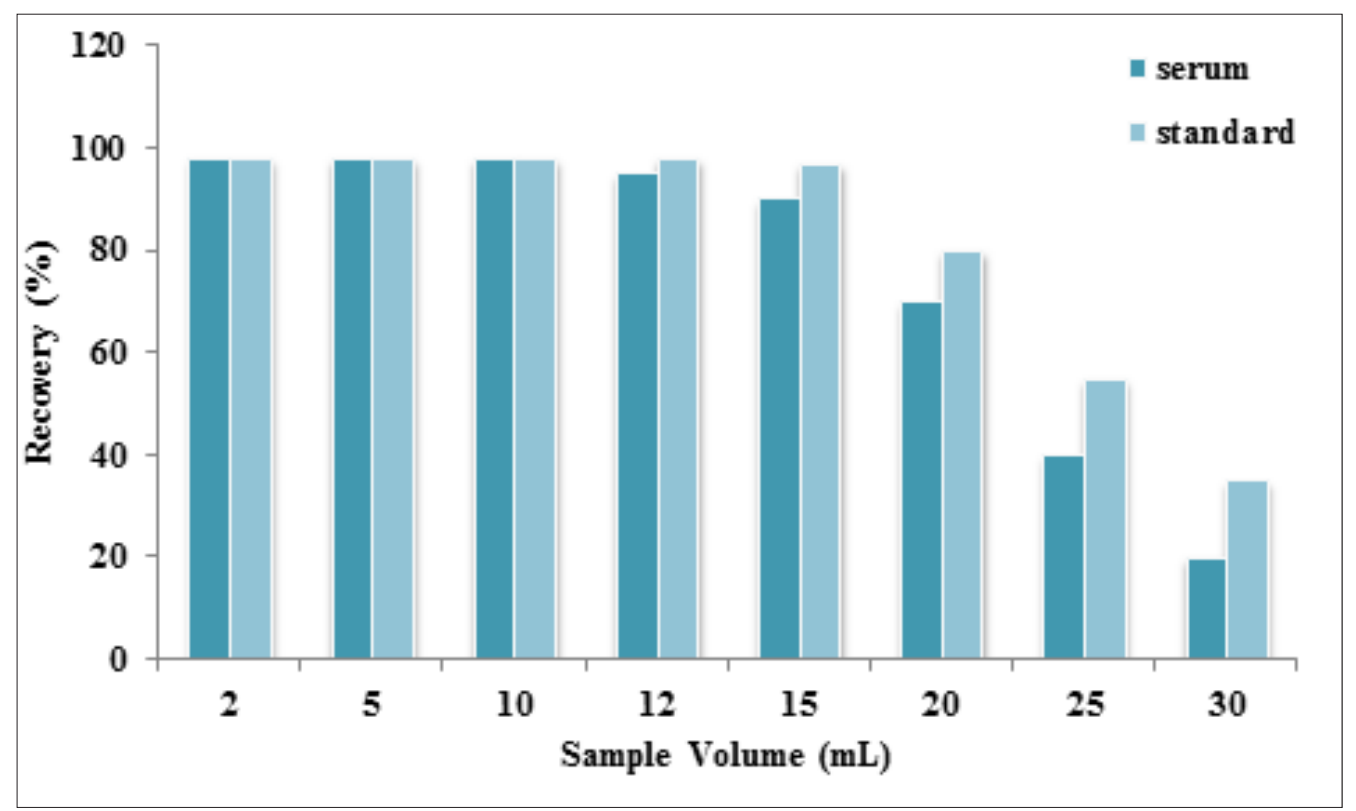

Fig. 9. The effect of sample volume on mercury extraction

\subsubsection{Effect of ILs for mercury extraction}

The IL was investigated as effective parameter for mercury absorption between 5-100 $\mathrm{mg}$, and the optimized result was selected $50 \mathrm{mg}$. A hydrophobic ionic liquids such as; [MMIM] $\left[\mathrm{PF}_{6}\right]$, [HMIM] $\left[\mathrm{PF}_{6}\right]$ and $[\mathrm{OMIM}]\left[\mathrm{PF}_{6}\right]$ as a green solvent was used to separate MOF from the serum and standard solution (Fig. 10). The different amount of IL (5$100 \mathrm{mg})$ for separation of $\left[\mathrm{Zn}_{2}(\mathrm{bdc})_{2}(\mathrm{dabco})\right]_{\mathrm{n}}$ from serum phase were used and examined. The results showed us, the good recovery was achieved with 65 $\mathrm{mg}$ of $[\mathrm{HMIM}]\left[\mathrm{PF}_{6}\right]$ and $45 \mathrm{mg}$ of [OMIM] $\left[\mathrm{PF}_{6}\right]$. Therefore, $50 \mathrm{mg}$ of $[\mathrm{OMIM}]\left[\mathrm{PF}_{6}\right]$ was selected by proposed method. In addition, the effect of [OMIM][PF6] for extraction of mercury in serum matrix was investigated without $\left[\mathrm{Zn}_{2}(\mathrm{bdc})_{2}(\mathrm{dabco})\right]$ n sorbents. The results showed us, the extraction recoveries of $\mathrm{Hg}$ were obtained about $12 \%$ by $\left[\mathrm{Zn}_{2}(\mathrm{bdc})_{2}(\mathrm{dabco})\right]_{\mathrm{n}}$ which was depended to amino acid complexation in serum.

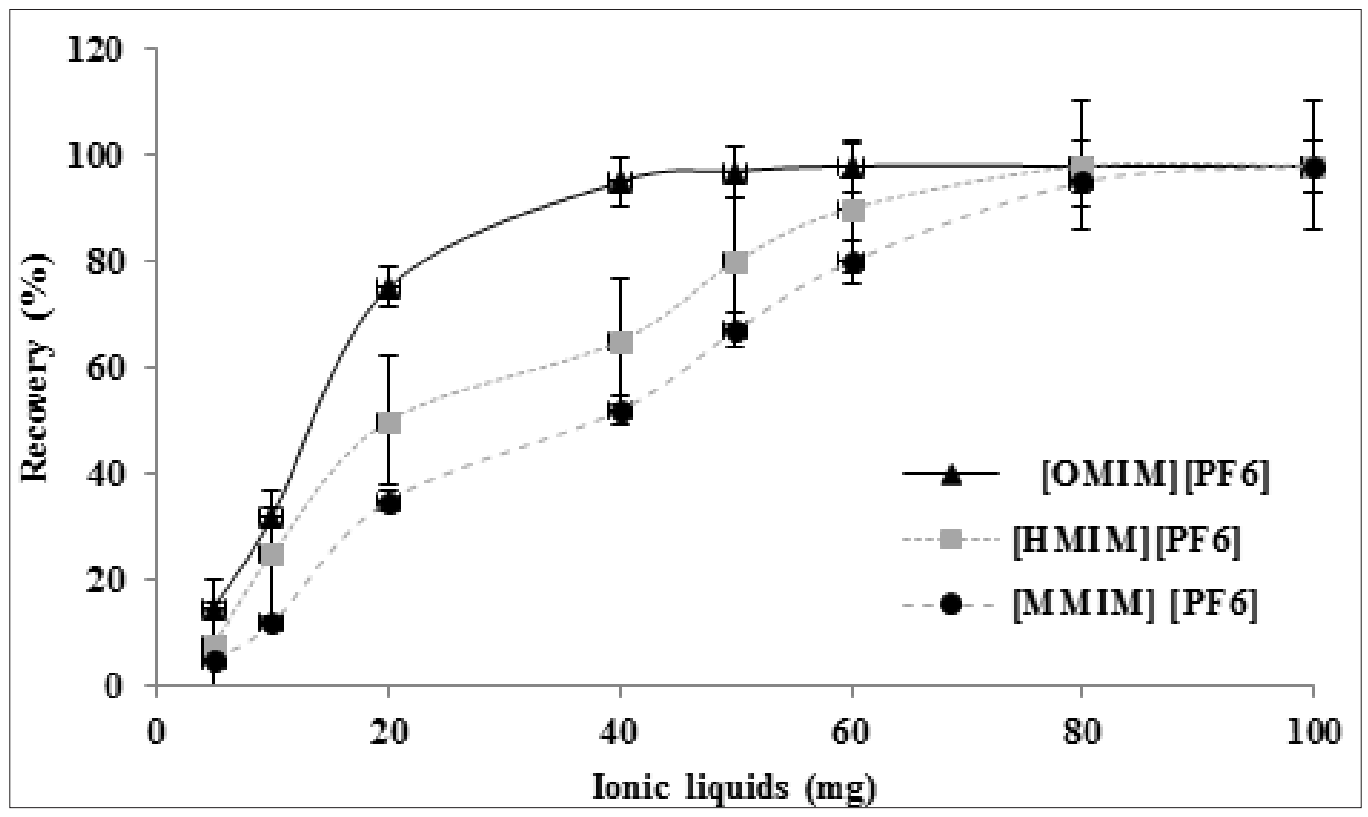

Fig. 10. The effect of different ionic liquids on mercury extraction 
Table 2. The interference of some coexisting ions in serum samples on the recovery of mercury ions under the optimal condition.

\begin{tabular}{lcccc}
\hline \multirow{2}{*}{ Ions } & \multicolumn{2}{c}{ Concentration ratio $\left(\mathbf{C}_{\text {interferent ion }} / \mathbf{C}_{\mathrm{Hg}}{ }^{2+}\right)$} & \multicolumn{2}{c}{ Mean of Recovery $(\%)$} \\
\cline { 2 - 5 } & Standard & Serum & Standard & Serum \\
\hline $\mathrm{Cr}^{3+}, \mathrm{Co}^{2+}, \mathrm{Pb}^{2+}, \mathrm{V}^{3+}, \mathrm{Mn}^{2+}$ & 500 & 400 & 96.4 & 95.9 \\
$\mathrm{I}^{-}, \mathrm{Br}^{-}, \mathrm{F}^{-}, \mathrm{NO}_{3}^{-}$, & 750 & 620 & 98.6 & 96.2 \\
$\mathrm{Na}^{+}, \mathrm{K}^{+}, \mathrm{Cl}^{-}, \mathrm{Ca}^{2+}, \mathrm{Mg}^{2+}$ & 1400 & 1100 & 97.7 & 95.1 \\
$\mathrm{Ni}^{2+}, \mathrm{Ag}^{+}, \mathrm{Cd}^{2+}$ & 35 & 20 & 99.3 & 97.5 \\
$\mathrm{Zn}^{2+}, \mathrm{Cu}^{2+}$ & 120 & 100 & 97.0 & 96.8 \\
\hline
\end{tabular}

\subsubsection{Adsorption capacity}

The important factor for analyzing of mercury with $\left[\mathrm{Zn}_{2}(\mathrm{bdc})_{2}(\mathrm{dabco})\right]_{\mathrm{n}}$ as MOF sorbent was adsorption capacity factor (ACF). In batch system, the ACF of $\mathrm{Hg}$ (II) was studied for $10 \mathrm{~mL}$ of human serum and standard solution at $\mathrm{pH}=8$. The ACF of MOF for mercury vapor in GC closed glass was $149.56 \mathrm{mg}$ $\mathrm{g}^{-1}$. Based on characteristics of $\left[\mathrm{Zn}_{2}(\mathrm{bdc})_{2}(\mathrm{dabco})\right]_{\mathrm{n}}$ the most ACF related to chemical bounding of MOF as compared to physical adsorption by MOF. So, $\left[\mathrm{Zn}_{2}(\mathrm{bdc})_{2}(\mathrm{dabco})\right]_{\mathrm{n}}$ with high ACF was considered as excellent MOF sorbent for extraction of $\mathrm{Hg}$ (II) from serum and standard solution samples.

\subsection{Interference Study}

By USA-IL- $\mu$-SPE procedure based on MOF for real samples, the interference of some coexisting ions encountered in serum samples on the recovery of $\mathrm{Hg}$ (II) ions was investigated under the optimal condition. This procedure was performed by adding various amounts of the interfering ions to $10 \mathrm{~mL}$ of standard sample solution containing $5.5 \mu \mathrm{g} \mathrm{L} \mathrm{L}^{-1}$ of $\mathrm{Hg}$ (II). Taking as criterion for interference the deviation of the recovery more than $\pm 5 \%$, the obtained results (Table 2) showed that most of the probable concomitant cations and anions had no considerable effect on the recovery efficiencies of
$\mathrm{Hg}$ (II) ions under the selected conditions.

\subsection{Validation of results}

The mercury absorption capacity was examined among different applications of MOF as hybrid inorganic-organic nanoporous materials by USA-IL- $\mu$-SPE method. The intra-day analysis of mercury was shown in Table 3 and based on this result; MOF is good candidate for mercury adsorption.

The USA-IL- $\mu$-SPE method was used for ultratrace mercury determination in standard solution and serum samples. The results based on average of three determinations, for $\mathrm{Hg}$ (II) were achieved in serum samples. For validation of results, real samples in serum and standard solution was verified by spiking of mercury standard concentration (Tables 4). The favorate recovery showed that the proposed method had good accuracy in serum matrix. The recoveries of spiked samples for serum and standard solution were obtained more than $95 \%$. The developed method based on MOF /IL was satisfactory demonstrated for mercury analysis in serum. The concentration of $\mathrm{Hg}$ in petroleum (subject) and office worker (control) were studied by USA-IL- $\mu$-SPE procedure $(\mathrm{N}=-$ 50). There were no significant differences between

Table 3. The intra-day analysis of mercury with MOF by USA-IL- $\mu-S P E$ method

\begin{tabular}{lcc}
\hline Parameter (Intra-day) & Serum sample & Standard sample \\
\hline $\mathrm{PF}^{\mathrm{a}}$ & 9.8 & 10.2 \\
$\mathrm{LOD}^{\mathrm{b}}(\mathrm{n}=10, \mathrm{ng} \mathrm{L}$ & $-1)$ & 6.8 \\
$\mathrm{RSD}^{\mathrm{c}}(\mathrm{n}=6, \%)$ & 6.5 & 3.3 \\
Linear range $\left(\mu \mathrm{g} \mathrm{L}^{-1}\right)$ & 4.2 & $0.02-6.0$ \\
Correlation coefficient & $0.02-5.5$ & 0.9992 \\
\hline
\end{tabular}

${ }^{\mathrm{a}}$ Preconcentration factor, ${ }^{\mathrm{b}}$ Limit of detection, ${ }^{\mathrm{c}}$ Relative standard deviation. 
Table 4. Validation of USA-IL- $\mu$-SPE method based on MOF/IL by spiking of mercury standard concentration in real samples $\left(\mu \mathrm{g} \mathrm{L}^{-1}\right)$

\begin{tabular}{lccc}
\hline Sample & Added & Found $^{\mathbf{a}}$ & Recovery (\%) \\
\cline { 2 - 4 } & Hg (II) & Hg(II) & Hg(II) \\
\hline \multirow{3}{*}{ Serum } & ----- & $0.48 \pm 0.02$ & ---- \\
& 0.5 & $0.97 \pm 0.05$ & 98 \\
\hline \multirow{3}{*}{ Serum } & 1.0 & $1.51 \pm 0.07$ & 103 \\
& ----- & $2.55 \pm 0.13$ & ---- \\
& 1.0 & $3.52 \pm 0.12$ & 97 \\
Water & 2.0 & $4.48 \pm 0.23$ & 96.5 \\
& ------- \\
\multirow{3}{*}{ Water } & 1.0 & $3.11 \pm 0.14$ & 96 \\
& 2.0 & $4.07 \pm 0.21$ & 102 \\
\hline
\end{tabular}

${ }^{a}$ Mean of three determinations \pm confidence interval $(\mathrm{P}=0.95, \mathrm{n}=5)$

exposed subjects and unexposed controls in terms of age and sex. The mean concentration of mercury in control groups was obtained under $1.0 \mu \mathrm{g} \mathrm{L}^{-1}$. In addition, for validation of methodology, standard reference material (SRM 1641e) for inorganic mercury was analyzed by MOF/IL. The results of the SRM were satisfactorily mercury range with the certified values. Table 5 was approved the validation of developed USA- IL- $\mu$-SPE method based on MOF with SRM 1641e standard reference material.

\section{Conclusions}

In this study, $\mathrm{Zn}_{2}(\mathrm{BDC})_{2}(\mathrm{DABCO}) \mathrm{MOF}$ was synthesized by solvothermal method at $90{ }^{\circ} \mathrm{C}$ for $3 \mathrm{~h}$ via the self-assembly metal centers and linkers using DMF solvent. Based on the results, the MOF was propped as a good candidate for mercury absorption. The highest mercury absorption was observed in $\mathrm{pH}=8$, mass of MOF $20 \mathrm{mg}$, volume of serum $10 \mathrm{ml}$, volume of water $15 \mathrm{ml}$, and IL optimized $50 \mathrm{mg}$ in presence of $\mathrm{HNO}_{3}$ as optimized acid. Also, the interference of concomitant cations and anions had no considerable effect on the recovery efficiencies of $\mathrm{Hg}$ (II) ions under the selected conditions. Therefore, these properties can be resulted to many advantages in the future to absorb of hazardous materials.

\section{References}

[1] N. Motakef-Kazemi, S.A. Shojaosadati, A. Morsali, Evaluation of the effect of nanoporous nanorods

Table 5. Validation of developed USA- IL- $\mu$-SPE method based on MOF with standard reference material (SRM)

\begin{tabular}{|c|c|c|c|c|}
\hline \multirow[t]{2}{*}{ Sample } & \multirow{2}{*}{$\begin{array}{c}\text { Certified } \\
\left(\mu g \mathrm{~L}^{-1}\right)\end{array}$} & \multirow{2}{*}{$\begin{array}{c}\text { Added } \\
\left(\mu g \mathrm{~L}^{-1}\right)\end{array}$} & Found a $\left(\mu \mathrm{g} \mathrm{L}^{-1}\right)$ & Recovery (\%) \\
\hline & & & \multicolumn{2}{|c|}{ Hg (II) } \\
\hline & & --- & $0.952 \pm 0.048$ & ---- \\
\hline \multirow[t]{3}{*}{ SRM $1641 \mathrm{e}^{\mathrm{b}}$} & $1.016 \pm 0.017$ & 0.5 & $1.446 \pm 0.087$ & 98.8 \\
\hline & & 1.0 & $1.921 \pm 0.126$ & 96.9 \\
\hline & & --- & $0.897 \pm 0.052$ & ---- \\
\hline \multirow[t]{2}{*}{ SRM $3668^{c}$} & $0.910 \pm 0.055$ & 0.5 & $1.380 \pm 0.092$ & 96.6 \\
\hline & & 1.0 & $1.875 \pm 0.103$ & 97.8 \\
\hline
\end{tabular}

${ }^{\mathrm{a}}$ Mean of three determinations \pm confidence interval $(\mathrm{P}=0.95, \mathrm{n}=5)$.

${ }^{\mathrm{b}}$ NIST, SRM 1641e, total mercury in water $(\mathrm{p}=0.95)$.

c Mercury in Frozen Human Urine 
$\mathrm{Zn}_{2}$ (bdc) ${ }_{2}$ (dabco) dimension on ibuprofen loading and release, J. Iran. Chem. Soc. 13 (2016) 12051212.

[2] S. Hajiashrafi, N. Motakef Kazemi, Preparation and evaluation of $\mathrm{ZnO}$ nanoparticles by thermal decomposition of MOF-5, Heliyon 5 (2019) e02152.

[3] N. Motakef-Kazemi, S.A. Shojaosadati, A. Morsali, In situ synthesis of a drug-loaded MOF at room temperature, Micropor. Mesopor. Mat. 186 (2014) 73-79.

[4] B. Miri, N. Motakef-Kazemi, S.A. Shojaosadati, A. Morsali, Application of a nanoporous metal organic framework based on iron carboxylate as drug delivery system, Iran. J. Pharm. Res. 17(4) (2018) 1164-1171.

[5] S.I. Noro, S. Kitagawa, M. Kondo, K. Seki, A new methane adsorbent, porous coordination polymer, Angew Chem. Int. Ed. 39 (2000) 2082-2084.

[6] K.S. Min, Self-assembly and selective guest binding of three-dimensional open-frame work solids from a macrocyclic complex as a trifunctional metal building block, Chem. Eur. J. 7 (2001) 303-313.

[7] M. Fujita, Y.J. Kwon, S. Washizu, K. Ogura, Preparation, clathration ability, and catalysis of a two-dimensional square network material composed of cadmium(II) and 4,4'-bipyridine, J. Am. Chem. Soc. 116 (1994) 1151-1152.

[8] O.R. Evans, W. Lin, Crystal engineering of NLO materials based on metal-organic coordination networks, Acc. Chem. Res. 35 (2002) 511-522.

[9] O.R. Evans, W. Lin, Crystal engineering of nonlinear optical materials based on interpenetrated diamondoid coordination networks, Chem. Mater. 13 (2001) 2705-2712.

[10] M. Oh, C.A. Mirkin, Ion exchange as a way of controlling the chemical compositions of nanoand microparticles made from infinite coordination polymers, Angew Chem. Int. Ed. 45 (2006) 54925494.

[11] R. Kitaura, S. Kitagawa, Y. Kubota, T.C. Kobayashi, K. Kindo, Y. Mita, A. Matsuo, M. Kobayashi, H. Chang, T.C. Ozawa, M. Suzuki, M. Sakata, M. Takata, Formation of a one-dimensional array of oxygen in a microporous metal-organic solid, Sci. 298 (2002) 2358-2361.

[12] P. Horcajada, T. Chalati, C. Serre, B. Gillet, C. Sebrie, T. Baati, J.F. Eubank, D. Heurtaux, P. Clayette, C.
Kreuz, J.S. Chang, Y.K. Hwang, V. Marsaud, P.N. Bories, L. Cynober, S. Gil, G. Ferey, P. Couvreur, R. Gref, Porous metal-organic-framework nanoscale carriers as a potential platform for drug delivery and imaging, Nat. Mater. 9 (2010) 172-178.

[13] B. Chen, L. Wang, F. Zapata, G. Qian, A luminescent microporous metal-organic framework for the recognition and sensing of anions, J. Am. Chem. Soc. 130 (2008) 6718-6719.

[14] A.J. Fletcher, K.M. Thomas, M.J. Rosseinsky, Flexibility in metal-organic framework materials: impact on sorption properties, J. Solid State Chem. 178 (2005) 2491-2510.

[15] M.D. Allendorf, C.A. Bauer, R.K. Bhakta, R.J.T. Houk, Luminescent metal-organic frameworks, Chem. Soc. Rev. 38 (2009) 1330-1352.

[16] S.M. Humphrey, T.J. Angliss, M. Aransay, D. Cave, L.A. Gerrard, G.F. Weldon, P.T. Wood, Bimetallic metal-organic frameworks containing the $[\mathrm{M} 2, \mathrm{x}-$ pdc $\left.)_{2}^{-2}\right](\mathrm{M}=\mathrm{Cu}, \mathrm{Pd}, \mathrm{Pt} ; \mathrm{x}=4,5)$ building blocksynthesis, structure, and magnetic properties, $\mathrm{Z}$. Anorg. Allg. Chem. 633 (2007) 2342-2353.

[17] C.G. Silva, A. Corma, H. García, Metal-organic frameworks as semiconductors. J. Mater. Chem. 20 (2010) 3141-3156.

[18] M. Hunsom, K. Pruksathorn, S. Damronglerd, H. Vergnes, P. Duverneuil, Electrochemical treatment of heavy metals $\left(\mathrm{Cu}^{2+}, \mathrm{Cr}^{6+}, \mathrm{Ni}^{2+}\right)$ from industrial effluent and modeling of copper reduction, Water Res. 39 (2005) 610-616.

[19] A. El-Samrani, B. Lartiges, F. Villiéras, Chemical coagulation of combined sewer overflow: heavy metal removal and treatment optimization. Water Res. 42 (2008) 951-960.

[20] H. Ozaki, K. Sharma, W. Saktaywin, Performance of an ultra-low-pressure reverse osmosis membrane (ULPROM) for separating heavy metal: effects of interference parameters, Desalination 144 (2002) 287-294.

[21] Z. Wang, J. Xu, Y. Hu, H. Zhao, H. Zhou, Y. Liu, Z. Lou, X. Xu, Functional nanomaterials: Study on aqueous $\mathrm{Hg}$ (II) adsorption by magnetic $\mathrm{Fe}_{3} \mathrm{O}_{4} @$ $\mathrm{SiO}_{2}-\mathrm{SH}$ nanoparticles, J. Taiwan Inst. Chem. Eng. 60 (2016) 394-402.

[22] L. Rahmanzadeh, M. Ghorbani, M. Jahanshahi, Effective removal of hexavalent mercury from aqueous solution by modified polymeric nanoadsorbent, J. Water Environ. Nanotechnol. 1 
(2016) 1-8.

[23] K. Yaghmaeian, R. Khosravi Mashizi, S. Nasseri, A.H. Mahvi, M. Alimohammadi, S. Nazmara, Removal of inorganic mercury from aquatic environments by multi walled carbon nanotubes, J. Environ. Health Sci. Eng. 13 (2015) 55.

[24] Q.D. Qin, J. Ma, K. Liu, Adsorption of nitrobenzene from aqueous solution by MCM-41, J. Colloid Interface Sci. 315 (2007) 80-86.

[25] L. Xie, D. Liu, H. Huang, Q. Yang, C. Zhong, Efficient capture of nitrobenzene from waste water using metal-organic frameworks, Chem. Eng. J. 246 (2014) 142-149.

[26] D.V. Patil, P.B. Somayajulu Rallapalli, G.P. Dangi, R.J. R.S. Tayade, Somani, H.C. Bajaj, MIL53(Al): An efficient adsorbent for the removal of nitrobenzene from aqueous solutions, Ind. Eng. Chem. Res. 50 (2011) 10516-10524.

[27] N. T. Abdel-Ghani, G. A. El-Chaghaby, F. S. Helal, Individual and competitive adsorption of phenol and nickel onto multiwalled carbon nanotubes, J. Adv. Res. 6 (2015) 405-415.

[28] Z. Zhaoa, X. Li, Z. Li, Adsorption equilibrium and kinetics of p-xylene on chromium-based metal organic framework MIL-101, Chem. Eng. J. 173 (2011) 150-157.

[29] A.A. Adeyemo, I.O. Adeoye, O.S. Bello, Metal organic frameworks as adsorbents for dye adsorption: overview, prospects and future challenges, Toxicol. Environ. Chem. 94(10) (2012) 1846-1863.

[30] M.M. Tong, D.H. Liu, Q.Y. Yang, S. DevautourVinot, G. Maurin, C.L. Zhong, Influence of framework metal ions on the dye capture behavior of MIL-100 (Fe, Cr) MOF type solids, J. Mater. Chem. A 1 (2013) 8534-8537.

[31] M.A. Al-Ghouti, M.A.M. Khraisheh, S.J. Allen, M.N. Ahmad, The removal of dyes from textile wastewater: a study of the physical characteristics and adsorption mechanisms of diatomaceous earth, J. Environ. Manage. 69 (2003) 229-238.

[32] J. Galán, A. Rodríguez, J.M. Gómez, S.J. Allen, G.M. Walker, Reactive dye adsorption onto a novel mesoporous carbon, Chem. Eng. J. 219 (2013) 62-68.

[33] A. Sayari, S. Hamoudi, Y. Yang, Applications of pore-expanded mesoporous silica: removal of heavy metal cations and organic pollutants from wastewater, Chem. Mater. 17 (2005) 212-216.

[34] S. Babel, T.A. Kurniawan, Low-cost adsorbents for heavy metals uptake from contaminated water: a review, J. Hazard. Mater. B97 (2003) 219-243.

[45] L. Rasuli, A.H. Mahvi, Removal of humic acid from aqueous solution using $\mathrm{MgO}$ nanoparticles, $\mathrm{J}$. Water Chem. Tech. 38(1) (2016) 21-27.

[36] M.R. Mehmandoust, N. Motakef-Kazemi, F. Ashouri, Nitrate adsorption from aqueous solution by metal-organic framework MOF-5, Iran. J. Sci. Technol. Trans. A-Science. 43(2) (2019) 443-449.

[37] A. Bhatnagara, E. Kumarb, M. Sillanpää, Nitrate removal from water by nano-alumina: Characterization and sorption studies, Chem. Eng. J. 163 (2010) 317-323.

[38] J.D. Park, W. Zheng, Human exposure and health effects of inorganic and elemental mercury, J. Prev. Med. Public Health 45 (2012) 344-352.

[39] M.A. Bradley, B.D. Barst, N. Basu, A review of mercury bioavailability in humans and fish, Int. J. Environ. Res. Public Health 14 (2017) 169.

[40] B.F. Azevedo, L.B. Furieri, F.M. Pecanha, G.A. Wiggers, P.F. Vassallo, M.R. Simoes, J. Fiorim, P.R. Batista, M. Fioresi, L. Rossoni, I. Stefanon, M.J. Alonso, M. Salaices, D.V. Vassallo, Toxic effects of mercury on the cardiovascular and central nervous systems, J. Biomed. Biotechnol. 2012 (2012) 1-11.

[41] K.M. Rice, E.M. Walker Jr, M. Wu, C. Gillette, E.R. Blough, Environmental mercury and its toxic effects, J. Prev. Med. Public Health 47 (2014) 74 83.

[42] S.E. Orr, C.C. Bridges, Chronic kidney disease and exposure to nephrotoxic metals, Int. J. Mol. Sci. 18 (2017) 1039.

[43] E. Afshar, H. Mohammadi-Manesh, H. Dashti Khavidaki, Removal of $\mathrm{Hg}$ (I) and $\mathrm{Hg}$ (II) ions from aqueous solutions, using $\mathrm{TiO}_{2}$ nanoparticles, Pollution. 3 (2017) 505-516.

[44] K. Suresh Kumar Reddy, B. Rubahamya, A. Al Shoaibi, C. Srinivasakannan, Solid support ionic liquid (SSIL) adsorbents for mercury removal from natural gas, Int. J. Environ. Sci. Technol. 16 (2019) 1103-1110. 